\title{
EGFR NM_005228.3:c.2125_2129delGAAAC
}

National Cancer Institute

\section{Source}

National Cancer Institute. EGFR NM 005228.3:C.2125 2129de/GAAAC. NCI Thesaurus.

Code C98531.

A change in the amino acid composition of the epidermal growth factor receptor protein where a frameshift mutation results in the placement of a stop codon just after the glutamic acid residue at position 709. 